\title{
Excavation topography modelling in the context of adaptation to climate change on the example of "Brzeziny" Natural Aggregate Mine
}

\author{
Katarzyna Pawełczyk ${ }^{1, *}$ \\ ${ }^{1}$ AGH University of Science and Technology, Faculty of Mining and Geoengineering, Department of \\ Surface Mining, 30 Mickiewicza Av, 30-059 Kraków, Poland
}

\begin{abstract}
One of the key activities of adapting to climate change is the revitalization of post-industrial areas. A special case of such areas are post-mining areas in the mining of rock raw materials, which as a result of opencast mining have a completely different characteristics from the surrounding landscape. Therefore, there is a great need to undertake actions aimed at adapting post-mining areas to climate change. However, to properly design these activities, a method should be defined to assess the level of adaptation of post-mining land to climate change. For its needs, the Topographic Adaptation Index was developed and applied in this paper. In order to determine the level of adaptation to climate change in the studied mine, three models were created in which the course of the Topographic Adaptation Index was analysed depending on the variable spatial conditions.
\end{abstract}

\section{Introduction}

Climate change and its intensifying effects pose a serious threat to the environment and, consequently, to the societies that live in it. In response to these changes, two types of activities are undertaken - mitigation and adaptation [1]. Adaptation activities should be understood as actions aimed at adapting a given area to climate change [2]. Extremely important factors affecting the adaptation of the post-mining area to climate change are, inter alia: the land use and the degree of anthropogenic transformation or the share of biologically active area and the presence of water reservoirs, which together constitute the blue-green infrastructure [3]. These elements form a group of landscape conditions. Examination of these conditions leads to obtaining quantitative and qualitative information about the resources and functioning of a given ecosystem. It should be mentioned that space with different features may play an important role in mitigating the effects of extreme phenomena [4]. Landscape conditions may therefore be key elements in assessing the adaptive capacity of post-mining areas, which is why it is extremely important to carry out extensive research and observation of the transformation of the post-industrial environment [5] and the impact of these transformations on adaptation capabilities. The first and essential step is to assess the ability to adapt to climate change [3].

\footnotetext{
*Corresponding author: pawelczyk@agh.edu.pl
} 


\section{Research method}

In order to determine the impact of the topography of the excavation and its immediate environment on the adaptation of this area to climate change, based on previous literature studies [1, 3-8] on the issue of adaptation to climate change, a dependence has been determined taking into account factors affecting the terrain ability to adapt from a spatial point of view.

$$
I_{T A}=\frac{\overline{V Q}_{w} \cdot A_{b i o} \cdot S D I}{\overline{D S}_{w} \cdot A_{i m p}}
$$

Where: I IA - Topographic Adaptation Index, $\overline{\mathrm{VQ}}_{\mathrm{w}}$ - weighted average of vegetation quality, Abio - share of biologically active area, SDI - Shannon Diversity Index, $\overline{\mathrm{DS}}_{\mathrm{w}}$ - weighted average degradation susceptibility, $A_{\text {imp }}$ - share of the impermeable surface.

Based on the topographic map, orthophotomap and field studies, the mine area and its immediate surroundings were divided into patches depending on the area development category. Then the areas of the patches and their percentage share in the area of the entire analyzed area and in the area of the mine were determined. For each patch located in the mine, the assessment of vegetation quality and degradation susceptibility according to Table 1 were determined.

Table 1. Vegetation quality and degradation susceptibility grade. Source: own study.

\begin{tabular}{|c|c|c|}
\hline Grade & Vegetation quality & Degradation susceptibility \\
\hline 1 & Very transformed areas / no vegetation & Very low susceptibility \\
\hline 2 & Transformed areas & Low susceptibility \\
\hline 3 & Areas with an average value & Average susceptibility \\
\hline 4 & Areas close to natural & High susceptibility \\
\hline 5 & Natural areas & Very high susceptibility \\
\hline
\end{tabular}

The assessment of these indicators was made on the basis of a local vision at the mine, documentation of reclamation [9] and analysis of factors related to landform.

Subsequently, the surface share of the patches of different categories in the mine was summed up and for each category the weighted average of vegetation quality and degradation susceptibility was calculated. The surface shares of the category were assumed as weights.

In the next stage of the research three models were created, for which the variability of the Topographic Adaptation Index was analyzed depending on the change of the set parameters.

\section{Characteristics of the study area}

The "Brzeziny" Natural Aggregate Mine, which is the study area, is located in the Skoroszyce commune in the Nysa poviat in the Opolskie Voivodeship. Geographically, the area is located in the Nysa Kłodzka Valley in the Silesian Lowland, which is one of the 
most abundant in natural aggregates in the entire country. The landscape is characterized by flat terrain and domination of agricultural land development. In the immediate vicinity of the mine there are also small patches of trees and meadow, and areas covered with grassy vegetation of low value around the flooded excavation (Figure 1).

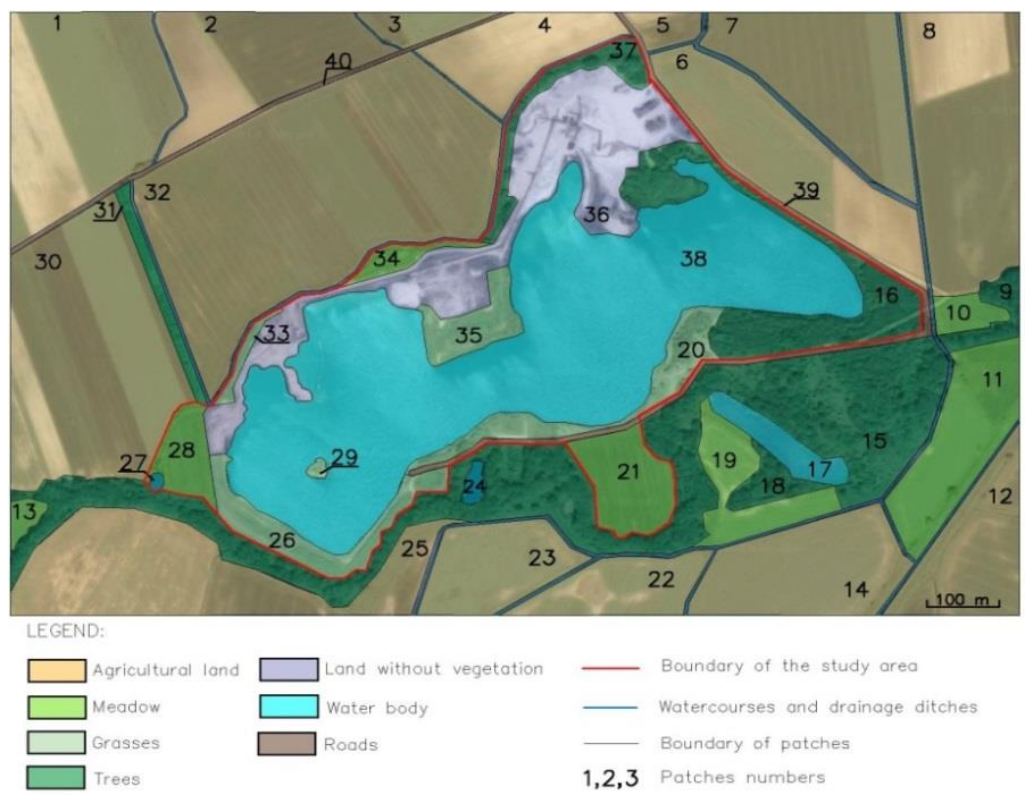

Fig. 1 Development of the immediate environment of the mine. Source: own study.

The surface of the patches shown on fig. 1 is $1.35 \mathrm{~km}^{2}$, while the area of the mine is $0.43 \mathrm{~km}^{2}$.

The basic parameters for calculating the Topographic Adaptation Index (1) of the mine area have been included in the Table 2 .

Table 2. Topographic Adaptation Index for mine area. Source: own study.

\begin{tabular}{|c|c|c|c|c|c|}
\hline $\begin{array}{c}\text { Weighted } \\
\text { average of } \\
\text { vegetation } \\
\text { quality }\end{array}$ & $\begin{array}{c}\text { Weighted } \\
\text { average } \\
\text { degradation } \\
\text { susceptibility }\end{array}$ & $\begin{array}{c}\text { Shannon } \\
\text { Diversity } \\
\text { Index }\end{array}$ & $\begin{array}{c}\text { Share of } \\
\text { biologically } \\
\text { active area }\end{array}$ & $\begin{array}{c}\text { Share of the } \\
\text { impermeable } \\
\text { surface }\end{array}$ & $\begin{array}{c}\text { Topographic } \\
\text { Adaptation } \\
\text { Index }\end{array}$ \\
\hline 3.42 & 3.29 & 0.57 & 0.83 & 0.17 & $\mathbf{2 . 9 9}$ \\
\hline
\end{tabular}

\section{Results and discussion}

In this chapter, the results of three models showing the variability of the Topographic Adaptation Index in the mine have been analyzed and discussed.

\subsection{Model 1}

The first model assumes a change in the surface share of selected development categories with constant vegetation quality and degradation susceptibility for individual patches. In order to observe the entire change process of the Topographic Adaptation Index, the change in the share of the area of a given category was tracked in the range from the current status for a given category to cover over $95 \%$ of the area covered by this category. 
The first variant increased the share of trees. The change of road development was not taken into account. In the first variant Topographic Adaptation Index changes are shown in Figure 2 .

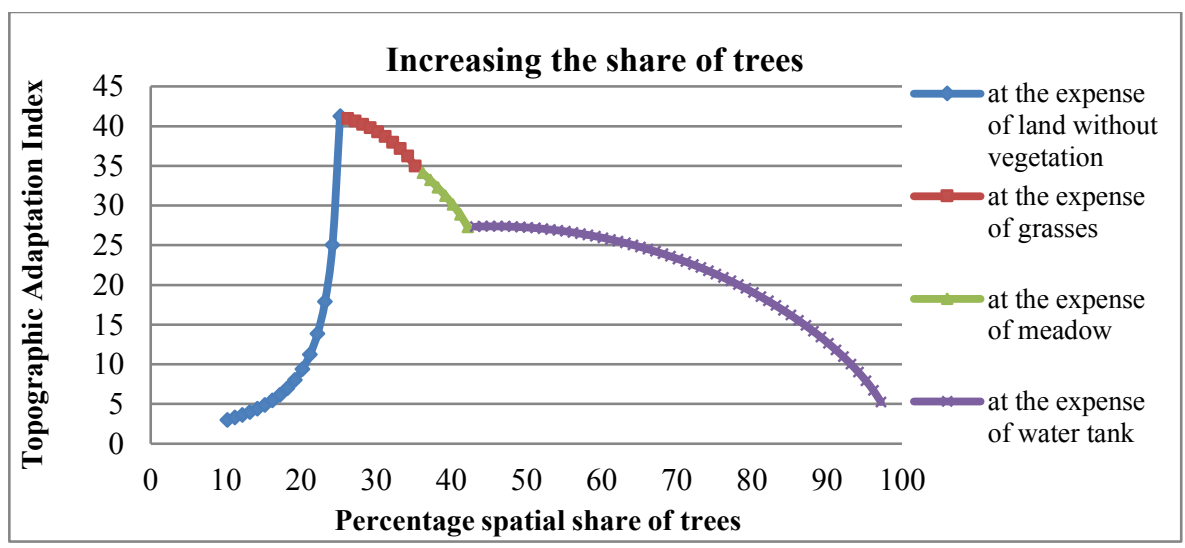

Fig. 2. Variability of the topographic adaptation index with the increase of the share of trees. Source: own study.

The highest value of the Topographic Adaptation Index was obtained by increasing the share of trees to the level of $25.2 \%$ and reducing the share of land without vegetation to the level of $0.9 \%$. Then, when changing the development of grasses, meadow and water body, the value of the indicator begins to decrease, with the drop being faster for the first two categories.

In the second variant, the share of meadow was increased.. As in the first variant, the share of roads remained unchanged. In the second variant changes in the Topographic Adaptation Index are shown in Figure 3.

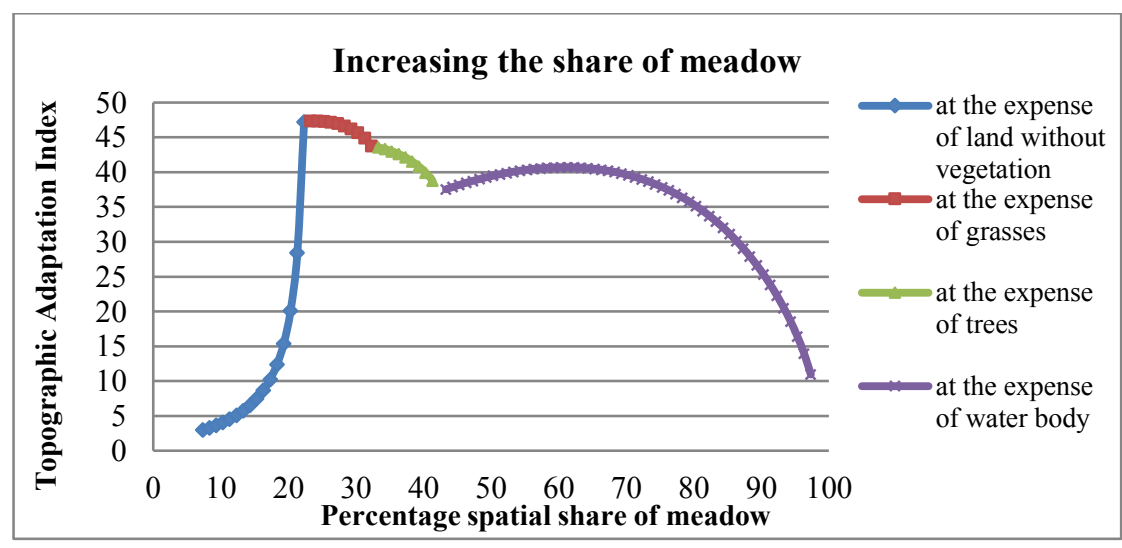

Fig. 3. Variability of the topographic adaptation index with the increase of the share of trees. Source: own study.

In the case of increasing the share the meadow Topographic Adaptation Index achieved the highest value for $24.33 \%$ coverage by meadow, while the share of land without vegetation decreased to $0.9 \%$ and the share of grasses was reduced to $8.4 \%$.This increase is due to a slightly higher vegetation quality index and a lower degradation susceptibility index for meadow compared to trees. 
The third variant assumes an even increase in the share of trees and meadow by $1 \%$. In the third variant changes are shown in the Topographic Adaptation Index in Figure 4.

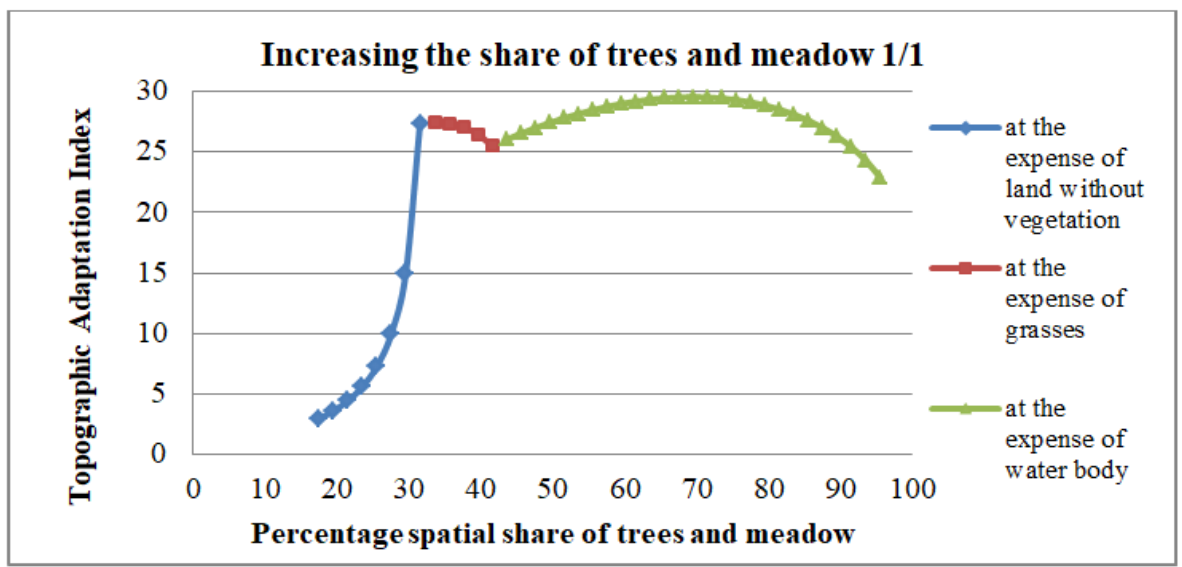

Fig. 4. Variability of the topographic adaptation index with the increase of the share of trees and meadow $1 / 1$. Source: own study.

Due to the irrationality of the water body development changes, further consideration will be given to the maximum $\mathrm{I}_{\mathrm{TA}}$ value for increasing the share of trees and meadow at the expense of land without vegetation and grasses, which combined share of trees and meadows of $33.6 \%$ with a spatial reduction share of land without vegetation is $1.9 \%$ and spatial share of grasses is $8.4 \%$.

Variant fourth assumes an increase in the surface share trees and meadow in the ratio of $0.5 \%$ trees and $1 \%$ meadow, which is dictated by better vegetation quality and degradation susceptibility of meadow. Changes in the Topographic Adaptation Index are shown in Fig. 5.

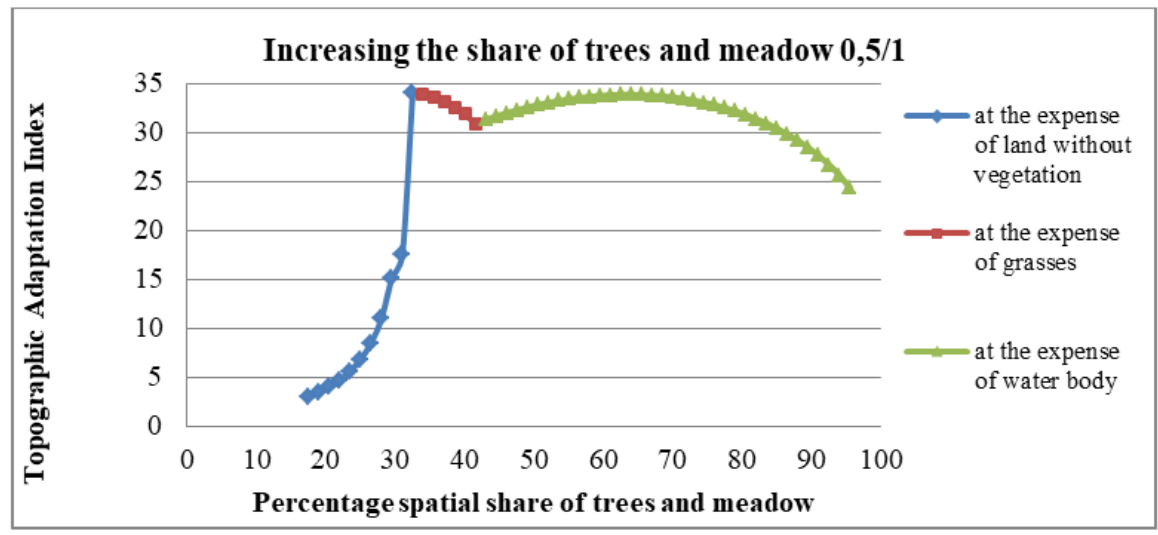

Fig.5. Variability of the topographic adaptation index with the increase of the share of trees and meadow $0,5 / 1$. Source: own study.

The shape of the graph for the fourth variant (Figure 5) is similar to the third variant (Figure 4), with the highest Topographic Adaptation Index being reached to increase the share of trees and meadow at the expense of land without vegetation and amounts to 34.13 with the total area share trees and meadow $32.56 \%$ when reducing spatial share of land without vegetation is $0.9 \%$. 
Maximum values of the Topographic Adaptation Index after rejection of irrational values from the point of view of reclamation are placed in Table 3. The best result was obtained for the second variant. This is related to the best vegetation quality and degradation susceptibility ratings for this category.

Table 3. A summary of the results of model . Source: own study.

\begin{tabular}{|c|c|}
\hline Variant & Topographic Adaptation Index \\
\hline 1 & 41.21 \\
\hline 2 & $\mathbf{4 7 . 3 5}$ \\
\hline 3 & $\mathbf{4 0 . 3 4}$ \\
\hline 4 & $\mathbf{2 7 . 3 9}$ \\
\hline 5 & $\mathbf{3 4 . 1 3}$ \\
\hline
\end{tabular}

\subsection{Model 2}

The second model assumes the change of vegetation quality and degradation susceptibility parameters while maintaining constant surface shares of particular development categories. The assessment of these parameters was raised in the range from the present state to their maximum values - vegetation quality to 5 , and in the case of degradation susceptibility to 1 . In all variants, in the first step the value of the parameter was raised / lowered to the whole, and then by 1 point.

Results of raising or lowering only one parameter were unsatisfactory small so the change of the Topographic Adaptation Index was checked, while the weighted average of vegetation quality was increased and the weighted average of degradation susceptibility of particular categories was reduced in the same time with their constant surface share (Figure $6)$.

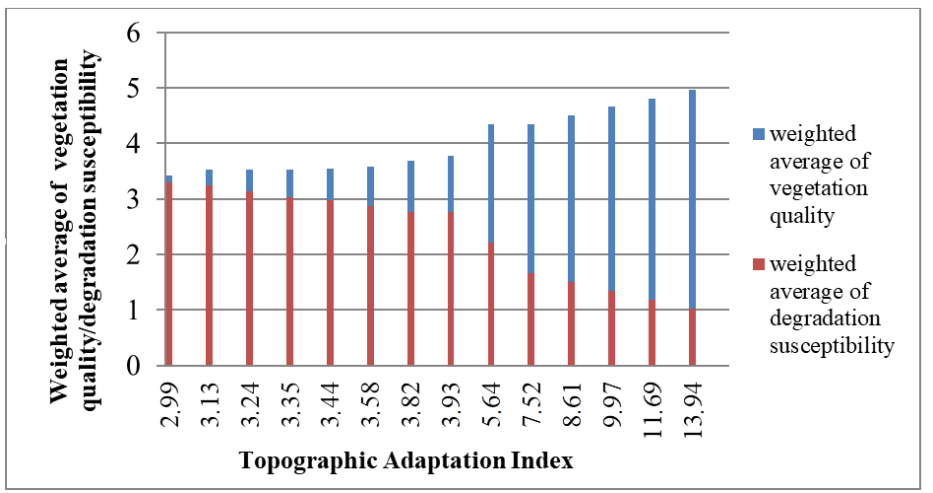

Fig.6. Variability of the topographic adaptation index with the increase of weighted average of vegetation quality and decrease of degradation susceptibility. Source: own study.

In the case of simultaneous increase of weighted average of vegetation quality and reduction of weighted average of degradation susceptibility, the highest value of $\mathrm{I}_{\mathrm{TA}}$ for model 2 was observed and amounted to 13.94 .

\subsection{Model 3}

The third model assumes both a change in the surface share of individual categories and a change in the parameters weighted average of vegetation quality and weighted average of degradation susceptibility. Based on the documentation [9] and the local vision, 
the maximum vegetation quality and degradation susceptibility for particular patches was assumed. They are the basis for determining all three variants of the model 3 .

The first variant assumes an increase in the share of the meadow, including the total conversion into this category of three patches which until now were grasses. Land without vegetation has been partially changed into grasses, trees and meadow. A small part was left as an impermeable surface.

In the second variant, one development category was added - the beach. Checking the Topographic Adaptation Index in such development is important from the revitalization point of view as it is becoming a more and more socially desirable direction in the case of flooded post-mining excavations [8].
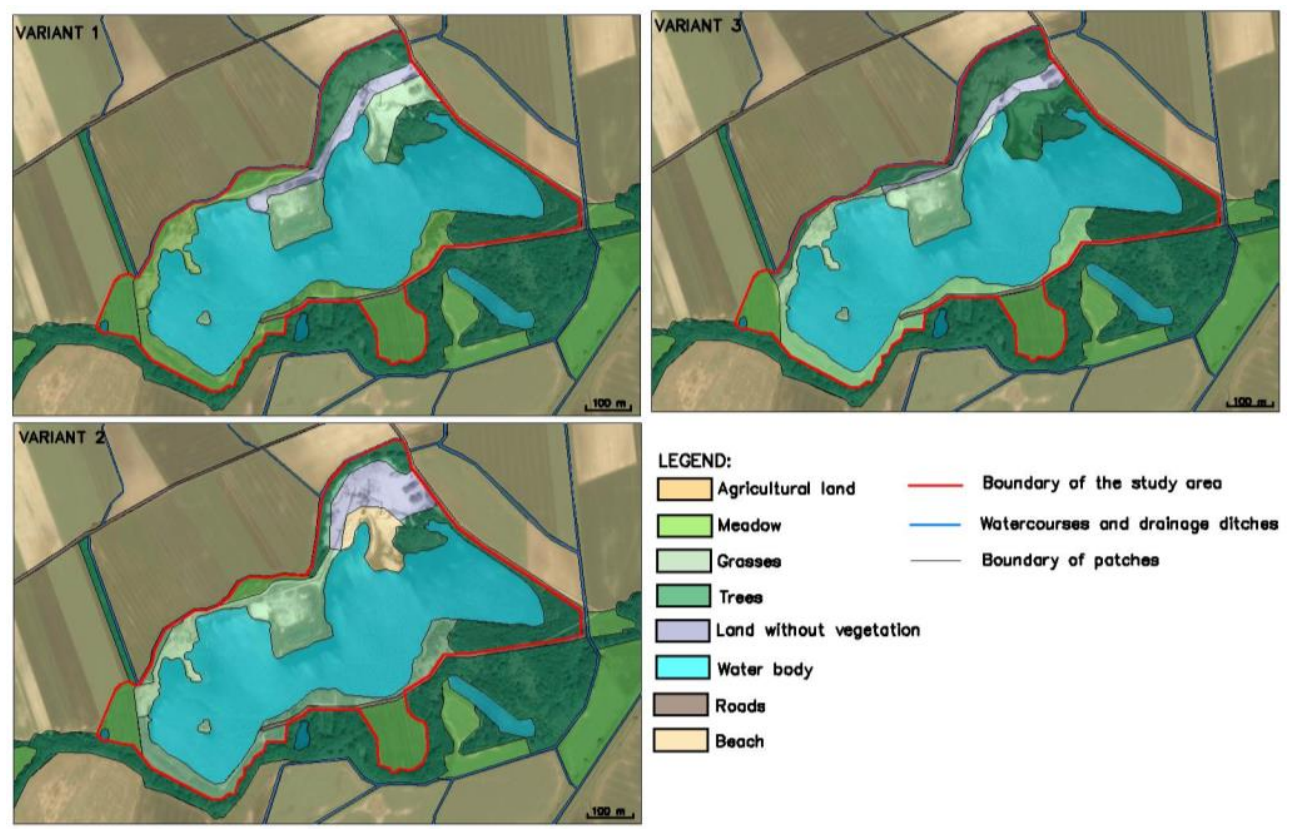

Fig. 74. Mine development in variant 2. Source: own study.

The third variant assumes increasing the share of trees, including replacing some patches for this category. The share of the impermeable surface in this variant is the smallest of the variants in the model 3. Values of Topographic Adaptation Index in model 3 are shown in Table 4 . The scheme of mine area development in variant 3 has been shown in Figure 7.

Table 4. Results of model 3. Source: own study.

\begin{tabular}{|c|c|}
\hline Variant & Topographic Adaptation Index \\
\hline 1 & $\mathbf{5 7 . 4 1}$ \\
\hline 2 & $\mathbf{4 7 . 3 7}$ \\
\hline 3 & $\mathbf{6 4 . 7 8}$ \\
\hline
\end{tabular}

\section{Summary}

Excavation topography modelling in the context of adaptation to climate change requires consideration of the most important activities related to adaptation to climate change [3, $5-7,10]$. The Topographic Adaptation Index (1) takes into account these elements, thanks to which it can illustrate the level of adaptation of the post-mining area due to spatial and 
landscape conditions. A comprehensive assessment of the level of adaptation to climate change requires consideration and development of other indicators too.

Modelling the topography of the "Brzeziny" Natural Aggregate Mine excavation in the context of adaptation to climate change gave rise to the following conclusions. The best results were achieved in the model 3, i.e. as a result of raising vegetation quality and lowering the degradation susceptibility to the maximum values that can be achieved by reclamation treatments for particular patches and then increase the surface share of categories exhibiting the best parameters. If the vegetation quality and degradation susceptibility parameters were changed only, the increase in the Topographic Adaptation Index was not satisfactory as it is shown in model 2. It is associated with a large surface share land without vegetation, which is classified as impermeable surface. Therefore, it is necessary to increase the share of biologically active area in degraded lands, which was shown in the model 1 , where the impermeable surface with poor parameters was occupied by categories with significantly better parameters - with such assumptions the Topographic Adaptation Index achieved a significant increase. However, the change in the surface share leading to the extreme domination of only one category, and thus the reduction of landscape diversity, even if it was a category with very good parameters, led to a reduction in the level of land adaptation. For comparison, the dominance of the two categories gave better results in the case of extreme dominance (the marginal share of the other categories). In the case of replacing only land without vegetation with a different category, definitely better results were given with introducing one, not two categories.

Taking into account the Topographic Adaptation Index at the stage of reclamation design will allow for a more appropriate selection of direction and function for the revitalized area, which has been shown in model 3. There is feedback between adaptive activities and reclamation and target development, therefore it is necessary to combine these actions in a rational and sustainable manner.

In order to formulate universal conclusions that may be applied in the broadly understood mining of rock raw materials, it is necessary to check how the Topographic Adaptation Index is formed in other post-mining areas and whether the dependencies observed on this study area can be referred to.

\section{References}

1. H.-M. Füssel, Sustain. Sci., 2, 265-275 (2007)

2. Stownik adaptacji. http://44mpa.pl/slownik-adaptacji/

3. J. Gorgoń, Znaczenie i rola zielono-błękitnej infrastruktury $w$ adaptacji do zmian klimatu (2016)

4. E. Roo-Zielińska, J. Solon, M. Degórski, Ocena stanu i przeksztatceń środowiska przyrodniczego na podstawie wskaźników geobotanicznych, krajobrazowych i glebowych (podstawy teoretyczne i przyktady zastosowań), (2007)

5. K. Gasidło, Problemy Ekologii, 12, 2, 76-80 (2008)

6. J. Gorgoń, Rewitalizacja miejsko-przemysłowa $w$ kontekście adaptacji do zmian klimatu (2016)

7. P. Kowalski, Czasopismo Techniczne. Architektura, 107, 2-A, 247-253 (2010)

8. J. Gorgoń et al., Ocena wrażliwości terenów miejskich na możliwe zagrożenia wynikajace ze zmian klimatu (2014)

9. Dokumentacja rekultywacji wyrobiska poeksploatacyjnego „,Brzeziny” (2015)

10. J. Badera, Surowce i Maszyny Budowlane, 5, 56 - 60 (2013) 